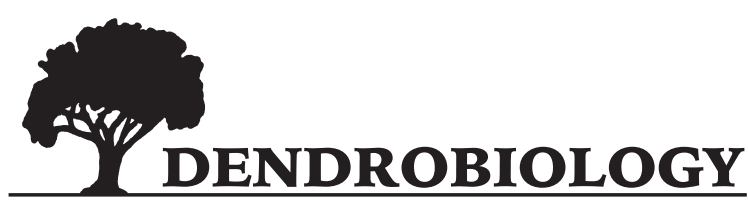

2014, vol. 72, 151-161

http://dx.doi.org/10.12657/denbio.072.013

\author{
Xiao Guo, Renqing Wang, Ruiying Chang, Xiaoqin Liang, Chengdong \\ Wang, Yujie Luo, Yifu Yuan, Weihua Guo*
}

\section{Effects of nitrogen addition on growth and photosynthetic characteristics of Acer truncatum seedlings}

Received: 24 September 2013; Accepted: 5 February 2014

\begin{abstract}
Increasing levels of atmospheric nitrogen deposition have greatly affected forest trees. Acer truncatum Bunge has a large distribution in northern China, Korea and Japan and plays an important ecological role in forest ecosystems. We investigated the responses of $A$. truncatum to a broad range of nitrogen addition regimes with a focus on seedling growth, biomass partitioning, leaf morphology, gas exchange physiology and chlorophyll fluorescence physiology. Moderate nitrogen addition promoted shoot height, stem diameter at ground height, total biomass, size of leaves and chlorophyll fluorescence and gas exchange performance, whereas extreme level of nitrogen addition did not result in such facilitation. Chlorophyll content, pattern of biomass partitioning, ratio of leaf length to width, leaf water content, and specific leaf area did not change among the addition regimes. The critical amount of nitrogen deposition should be defined in the context of a certain time period in a particular region for a certain species at a special developmental stage. The critical amount of $\mathrm{N}$ deposition that weakens total biomass facilitation in $A$. truncatum planted in mixed soil of yellow cinnamon soil and humic soil is approximately $10 \mathrm{~g} \mathrm{~N} \mathrm{~m}^{-2} \mathrm{y}^{-1}$ during the first growing season.
\end{abstract}

Additional key words: Morphology, Carbon assimilation, Chlorophyll fluorescence, Photosynthesis, High nitrogen load

Addresses: X. Guo, C. Wang, Y. Luo, Y. Yuan, W. Guo, Institute of Ecology and Biodiversity, School of Life Sciences, Shandong University, Jinan 250100, P.R. China; Shandong Provincial Engineering and Technology Research Center for Vegetation Ecology, Shandong University, Jinan 250100, P.R. China, e-mail: guo_wh@yahoo.com

R. Wang, Institute of Ecology and Biodiversity, School of Life Sciences, Shandong University, Jinan 250100, P.R. China; Shandong Provincial Engineering and Technology Research Center for Vegetation Ecology, Shandong University, Jinan 250100, P.R. China; Environment Research Institute, Shandong University, Jinan 250100, P.R. China

R. Chang, X. Liang, Environment Research Institute, Shandong University, Jinan 250100, P.R. China 


\section{Introduction}

Emissions and deposition rates of nitrogen are predicted to double from current values by 2050 , mainly due to anthropogenic activity which dominates the global nitrogen cycles, resulting more regions receiving potentially damaging levels of nitrogen inputs (Galloway et al. 2004; Phoenix et al. 2012). The amount of nitrogen deposition in the world varies remarkably among different regions (Dentener et al. 2006; Pardo et al. 2011; Reay et al. 2008).

Cellular and soil nitrogen status can be impacted by the rate and duration of nitrogen deposition, and deposition rates can exceed the capacity for nitrogen uptake by plants (Aber et al. 2003). Both positive and negative influences of nitrogen deposition on different species have been reported (Thomas et al. 2010), depending mainly on whether nitrogen saturation occurs under certain deposition rate (Hyvönen et al. 2006; Zhao and Liu 2009). However, the responses of forest trees (Elvir et al. 2006; Thomas et al. 2010) and shrubs (Bubier et al. 2011) to nitrogen deposition also depend on the physiological adaptations of the species present.

Acer truncatum Bunge is a forest tree species native to northern China, Korea and Japan (White and More 2003), and cultivated A. truncatum can also be found in Europe (White and More 2003) and northern America. As a characteristic species of temperature forest of China, it is important for its ecological, ornamental, and medicinal functions (Ma et al. 2005). Since its broad distribution covering both nature and urban ecosystem, this kind of maple trees is likely to be exposed to diverse levels of nitrogen loads. Some research concerning the impact of nitrogen deposition on a few species of the Aceraceae family has been reported (Elvir et al. 2006; Thomas et al. 2010). A. truncatum were often not included in these studies, and the chlorophyll fluorescence and gas exchange traits in response to nitrogen deposition were not performed in these species of the Aceraceae family.

The traditional concept of critical load was defined as the level of input of one or more pollutants below which sensitive environmental elements would not be significantly and negatively impacted (Nilsson and Grennfelt 1988; Porter et al. 2005). Both empirical and modeling approaches have been used to determine the critical load of nitrogen deposition; the former method was considered as the more reliable estimate of the threshold (Fenn et al. 2008) and its advantage is that it is based on measurable ecosystem responses to nitrogen loads (Pardo et al. 2011). We therefore established a pot experiment with the uniform growth substrates for plants among different treatment before the experiment and the growth environment was the same through the research pe- riod. Thus the divergence between treatments can only be attributed to different nitrogen loads.

In this research, both morphological measurements and physiological approaches were applied in investigating the responses of $A$. truncatum seedlings to nitrogen deposition by adding nitrogen to the growth substance. As atmospheric deposition of $\mathrm{N}$ is mainly emitted by fossil fuel combustion in form of $\mathrm{NO}_{\mathrm{X}}$, and $\mathrm{NH}_{3}$ derived from agricultural activities (Rennenberg et al. 2010), $\mathrm{NH}_{4} \mathrm{NO}_{3}$ was applied to simulate nitrogen load. A broad range of nitrogen load form low to high was established to simulate current and predicted future deposition levels. The objectives of our study were to (1) investigate the morphological and physiological strategies of $A$. truncatum seedlings for adaptation to nitrogen deposition and (2) obtain basic data for evaluating the critical level of nitrogen to protect this widespread species.

\section{Materials and Methods}

\section{Study site and plant materials}

The research was carried out at Fanggan Research Station of Shangdong University in Laiwu, Shandong Province, China $\left(36^{\circ} 26^{\prime} \mathrm{N}, 117^{\circ} 27^{\prime} \mathrm{E}\right)$. The site has a warm temperate monsoon climate, with an average temperature of $13 \pm 1{ }^{\circ} \mathrm{C}$, and an average annual precipitation of $700 \pm 100 \mathrm{~mm}$, most of which falls during the summer (Zhang et al. 2006). The soil type is yellow cinnamon soil, and the parent material is limestone. Natural precipitation was avoided by conducting the whole experiment in the greenhouse; the greenhouse was well ventilated by rolling up the plastic side films.

The seeds were purchased from Dacheng Seed Company (Jinan, China), where the seeds were collected in the company garden (Jinan, China) in early winter of 2010. The trees in this common garden which produced these seeds were also exposed to the atmospheric $\mathrm{N}$ deposition, which is equal to the trees in the forest. Furthermore, the common garden is not far (approximately $40 \mathrm{~km}$ ) from the research station where we grew the plants. Therefore these uniform seeds were not different from seeds produced by forest trees with respect to nitrogen deposition. The seeds were stored at $0-4{ }^{\circ} \mathrm{C}$ through the winter. Seeds were soaked in water for $24 \mathrm{~h}$ and preserved in wet gauze at $0-4{ }^{\circ} \mathrm{C}$ to stimulate germination in next May. The germinated seedlings were transferred into plastic pots (one seedling per pot) $320 \mathrm{~mm} \times 290$ $\mathrm{mm}$ (height $\times$ diameter). Yellow cinnamon soil and humic soil were air-dried and mixed $(2: 1, \mathrm{v} / \mathrm{v})$ to use as substrate in the pots. The total substrate weighed $7.0 \mathrm{~kg}$. Both the yellow cinnamon soil and humic soil were obtained in the local area near the station. 


\section{Experimental design}

Five nitrogen-addition treatments, 0 (no nitrogen added), 3, 6, 10, $20 \mathrm{~g} \mathrm{~N} \mathrm{~m}^{-2} \mathrm{y}^{-1}$ (N0, N1, N2, N3, N4, respectively) were conducted during the period from June 8 to September 20. There were seven replicates in each treatment. These treatments represent reference, low, moderate, high, and extremely high nitrogen addition, respectively. Nitrogen was added in the form of ammonium nitrate $\left(\mathrm{NH}_{4} \mathrm{NO}_{3}\right)$ solution every 15 days during the experiment period. Ammonium nitrate was weighed, dissolved in $200 \mathrm{ml}$ of water, and applied to each pot except for the reference pots. The reference pots were watered with $200 \mathrm{ml}$ of water without nitrogen when $\mathrm{NH}_{4} \mathrm{NO}_{3}$ was applied. All the seedlings were watered when necessary to avoid the influence of drought.

\section{Measurements}

Fully-expanded leaves (third or fourth leaves from the tip) were collected as the sample to measure pigment concentration, gas exchange parameters, chlorophyll fluorescence parameters, and leaf traits.

Chlorophyll a and chlorophyll b were extracted and measured according to the method of Lichtenthaler and Wellburn (Lichtenthaler and Wellburn 1983), using a visible light spectrophotometer $722 \mathrm{~S}$ (Leng Guang, Inc., ShangHai, China). Six replicates in every treatment were used to measure the concentrations of chlorophyll a and chlorophyll b.

Light response curve were measured on the leaves in situ with a portable leaf gas exchange system (GFS3000, Walz GmbH, Effeltrich, Germany). 12 levels of photosynthetically active radiation $(0,20,50,100$, $150,200,300,500,700,1000,2000,2500) \mu \mathrm{mol} \mathrm{m}^{-2}$ $\mathrm{s}^{-1}$, were applied to the leaves of the seedlings with no nitrogen addition. Irradiance was increased gradually to increase the incident PAR to $2500 \mu \mathrm{mol} \mathrm{m}^{-2}$ $\mathrm{s}^{-1}$. The net photosynthetic rate was recorded when steady-state was reached. Light response curve were fitted according to (Ye 2007). Three consecutive data with 5 seconds interval were recorded under each light condition for every leaf. Three leaves were taken from each seedling and three seedlings were taken in total $(n=3)$.

Gas-exchange characteristics, including net photosynthetic rate $(A)$, transpiration rate $(E)$, stomatal conductance (gs) and intercellular $\mathrm{CO}_{2}$ concentration (Ci) were measured in situ with the GFS-3000 instrument as well. PAR of $1200 \mu \mathrm{mol} \mathrm{m}{ }^{-2} \mathrm{~s}^{-1}$ (a PAR level that entitled the seedling reached relative high value of net photosynthetic rate, showed as the light response curve) was used in the measurement and provided by a red/blue light emitting diode. The characteristics were recorded when steady-state was reached. Instantaneous water use efficiency (WUEi) was calculated by formula WUE $=\mathrm{A} / \mathrm{E}$ (Nijs et al. 1997). Both light response curve and gas-exchange characteristics were measured between 9:00 and 11:30 (24h) on sunny days. All data were measured at average temperature inside the chamber of $30^{\circ} \mathrm{C}$, relative humidity of $70 \%$ and $\mathrm{CO}_{2}$ concentration inside the chamber of ambient level (approximate 380 ppm).

Chlorophyll fluorescence parameters were measured using a pulse amplitude modulation chlorophyll fluorometer (Mini-PAM, Walz GmbH, Effeltrich, Germany). Leaves were kept in dark for $30 \mathrm{~min}$ to ensure complete relaxation of all reaction centers before measurements on sunny days. Five replicates in every treatment were chosen to measure chlorophyll fluorescence parameters. The five replicates were included in the six replicates selected as chlorophyll content samples. The chlorophyll fluorescence parameters were measured before the leaves were collected to extract pigment.

Maximum PSII quantum yield $\left(\mathrm{F}_{\mathrm{v}} / \mathrm{F}_{\mathrm{m}}\right)$ was calculated as: $\mathrm{F}_{\mathrm{v}} / \mathrm{F}_{\mathrm{m}}=\left(\mathrm{F}_{\mathrm{m}}-\mathrm{F}_{0}\right) / \mathrm{F}_{\mathrm{m}}$, where $\mathrm{F}_{0}$ is the minimum chlorophyll fluorescence, determined using a measuring beam, and $\mathrm{F}_{\mathrm{m}}$ is the maximum chlorophyll fluorescence, recorded after $0.8 \mathrm{~s}$ saturating pulse of light (approximate $8,000 \mu \mathrm{mol} \mathrm{m} \mathrm{m}^{-2} \mathrm{~s}^{-1}$ ). Maximum fluorescence in the light-saturated stage $\left(\mathrm{F}_{\mathrm{m}}^{\prime}\right)$ and fluorescence yield in the steady state $\left(\mathrm{F}_{\mathrm{s}}\right)$ were determined after actinic light (approximate $402 \mu \mathrm{mol} \mathrm{m}^{-2}$ $\mathrm{s}^{-1}$ ) was applied and lasted 50 seconds to drive photosynthesis. $\mathrm{F}_{0}$ and $\mathrm{F}_{\mathrm{m}}$ were determined after the saturating pulse of light following the dark acclimation while $\mathrm{F}_{\mathrm{m}}$ and $\mathrm{F}_{\mathrm{s}}$ were determined in prevailing actinic light after the $\mathrm{F}_{0}$ and $\mathrm{F}_{\mathrm{m}}$ were recorded. Effective quantum yield (Yield) and relative photosynthetic electron transport (Etr) were calculated according to Genty et al (Genty et al. 1989). Photochemical quenching (qP) and non-photochemical quenching (qN) were calculated according to Schreiber et al (Schreiber et al. 1986).

Leaf morphology was measured in the middle of August. Five leaves from each treatment were scanned with a scanner (Epson Perfection V700, Seiko Epson, Japan). Leaf length, width, area, and perimeter were calculated with an image analyzer (Image-Pro Plus Version 4.5, Media Cybernetic Inc., Silver Spring, MD, USA) using the scanned images. The leaves were weighed before and after oven-drying at $80^{\circ} \mathrm{C}$ for 48 hours to calculate the water content of the leaves and specific leaf area.

At the end of the experiment, three seedlings in every treatment were chosen to record shoot height, stem diameter at ground height (approximate $1 \mathrm{~cm}$ above the ground line), and crown area. Then these seedlings were harvested and divided into six parts (fine lateral roots, coarse lateral roots, main root, stem, leaf blades and petioles). The main root was 

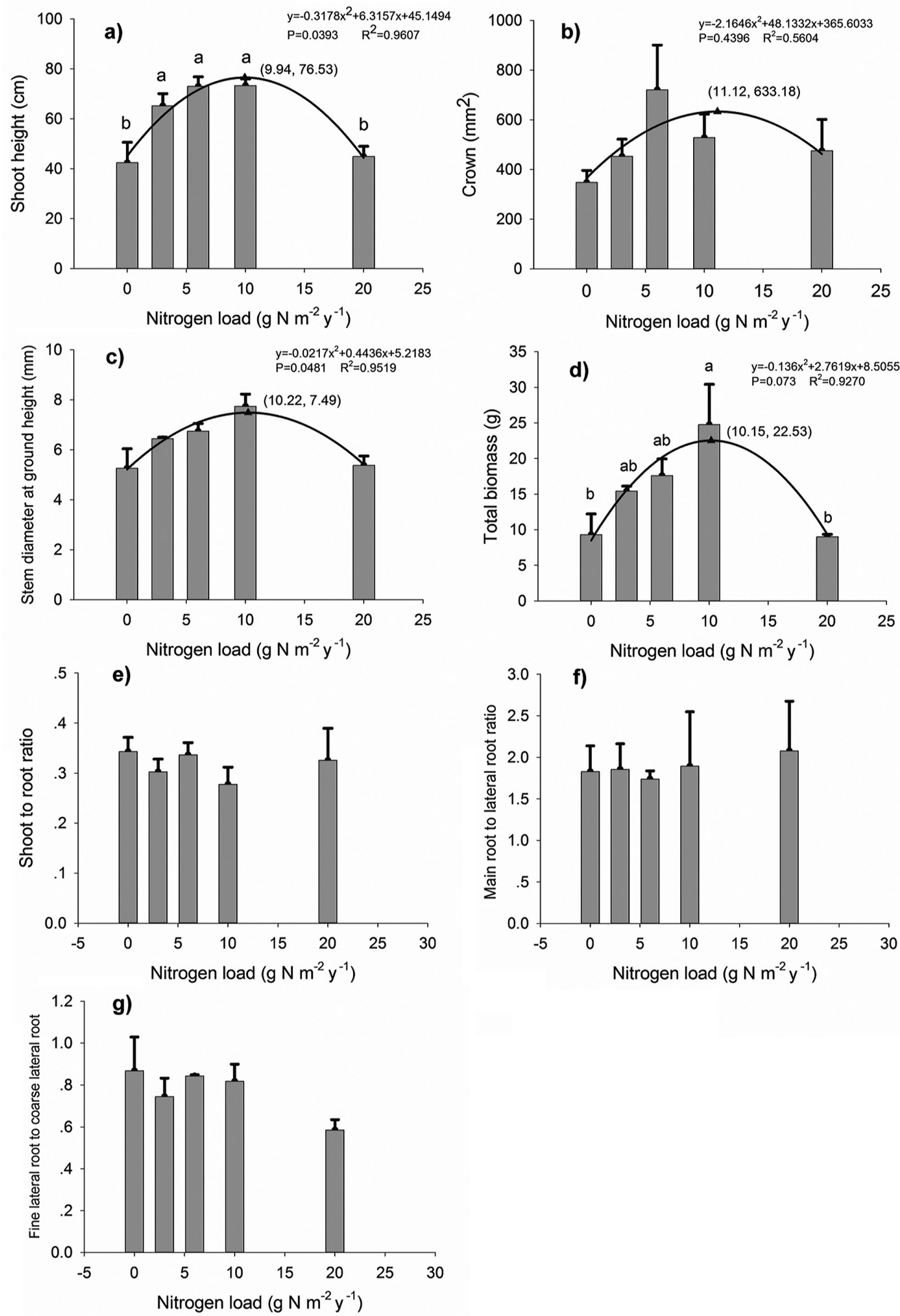

Fig. 1 Comparisons of shoot height (A), crown area (B), stem diameter at ground height (approximate $1 \mathrm{~cm}$ above the ground line, C), total biomass (D), root to shoot ratio (E), fine lateral root to coarse root ratio $(F)$ and main root to lateral root ratio $(\mathrm{G})$ of $A$. truncatum seedlings under different nitrogen treatments at the end of the experimental period. The data are means $\pm S E(n=3)$. Different letters indicate significant differences $(p \leq 0.05)$ with Duncan multiple range test 
Table. 1 Available soil nitrogen, available soil phosphorus and $\mathrm{pH}$ after the experiment under different nitrogen deposition regimes

\begin{tabular}{lcccccc}
\hline $\begin{array}{c}\text { Nitrogen load level }(\mathrm{g} \\
\left.\mathrm{m}^{-2} \mathrm{y}^{-1}\right)\end{array}$ & 0 & 3 & 6 & 10 & 20 & $\mathrm{P}$ \\
\hline Available $\left.\mathrm{N} \mathrm{(mg} \mathrm{kg}{ }^{-1}\right)$ & $52.30 \pm 2.0$ & $51.94 \pm 2.5$ & $53.06 \pm 3.0$ & $48.63 \pm 1.1$ & $48.75 \pm 1.4$ & $0.453^{\text {ns }}$ \\
Available P (mg kg & $16.24 \pm 0.8$ & $15.28 \pm 0.5$ & $16.58 \pm 0.9$ & $16.64 \pm 0.6$ & $18.29 \pm 0.4$ & $0.061^{\text {ns }}$ \\
$\mathrm{pH}$ & $6.66 \pm 0.06$ & $6.67 \pm 0.04$ & $6.63 \pm 0.03$ & $6.66 \pm 0.03$ & $6.52 \pm 0.05$ & $0.104^{\text {ns }}$ \\
\hline
\end{tabular}

The data are means \pm SE $(n=7)$. Significance level: * $0.01<P \leq 0.05 ; n s P>0.05$

defined as the root that developed directly from the seed, while the lateral roots were the roots that extended from the main root. Fine root was defined as the root with a diameter $<2 \mathrm{~mm}$, and the coarse root was defined as the root with a diameter $>2 \mathrm{~mm}$ (Berger and Glatzel 2001). Every part was weighed after oven-drying in $80^{\circ} \mathrm{C}$ for 48 hours.

Available soil nitrogen and available soil phosphorus before and after the experiment were analyzed using the alkali-diffusion method and Olsen method, respectively, at Shandong Agricultural University. The $\mathrm{pH}$ values were measured using a $\mathrm{pH}$-meter (PHSJ-3F, Shanghai Precision Scientific Instrument Co., Ltd, Shanghai, China) before and after the experiment as well. Six soil samples were selected before the experiment to represent soil background values. Soil samples from each pot (seven samples per treatment) were also collected after experiment.

\section{Statistical analysis}

One-way analysis of variance (one-way ANOVA) was applied to detect differences among the five treatments for every parameter. All one-way ANOVAs were accompanied by Duncan's multiple comparison tests, performed at a level of significance of 0.05. Before ANOVAs, data were checked for normality and homogeneity of variance. All of the statistical analyses were performed using the SPSS 13.0 software package (SPSS Inc., Chicago, IL, USA) and the figure was drawn using SigmaPlot 12.5 (Systat Software Inc., Chicago, IL, USA). Curve fitting in Figure 1 was carried out using quadratic equation by SigmaPlot 12.5 (Systat Software Inc., Chicago, IL, USA).

\section{Results}

The available soil nitrogen, available soil phosphorus and $\mathrm{pH}$ before the experiment were $57.64 \pm 1.34$ $\mathrm{mg} \mathrm{kg}-1,18.21 \pm 0.83 \mathrm{mg} \mathrm{kg}^{-1}$ and $6.68 \pm 0.058$, respectively. The available soil nitrogen, available soil phosphorus and $\mathrm{pH}$ after the treatment are displayed in Table 1. None of the three parameters was significantly different among the five nitrogen load levels.

Growth parameters and biomass parameters are shown in Fig. 1. Shoot height and stem diameter at ground height increased along with the increase of the amount of nitrogen addition and then decreased when the amount of nitrogen addition reached $20 \mathrm{~g}$ $\mathrm{N} \mathrm{m}^{-2} \mathrm{y}^{-1}$. The crown area illustrated the same trend although the differences among different treatments were not significant.

Total biomass displayed similar trends as occurred in shoot height (Fig. 1a). However, no significant difference was exhibited between N0 and N4 seedlings. Root to shoot ratio and main root to lateral root ratio (Fig. 1e, f) did not exhibit remarkable differences between different nitrogen addition treatments. The highest value of fine lateral to coarse lateral root ratio appeared in the control treatment and decreased as the amount of nitrogen load increased. According to the fitted curves, the maximum values of shoot height, crown area, stem diameter at ground height and total biomass occurred when the nitrogen load was approximately $10 \mathrm{~g} \mathrm{~N} \mathrm{~m}^{-2} \mathrm{y}^{-1}$ although some regressions were not significant (Fig. 1b, d).

The results of main leaf morphological characteristics under different nitrogen addition regimes are shown in Table 2. Leaf area and perimeter increased under moderate and high nitrogen addition and decreased to the reference level under the extreme high nitrogen load conditions. However, leaf length to leaf

Table. 2 Leaf morphological traits of A. truncatum seedlings under different nitrogen deposition regimes

\begin{tabular}{lcccccc}
\hline \multicolumn{1}{c}{\begin{tabular}{c} 
Nitrogen load level $(\mathrm{g}$ \\
\multicolumn{1}{c}{$\left.\mathrm{m}^{-2} \mathrm{y}^{-1}\right)$}
\end{tabular}} & 0 & 3 & 6 & 10 & 20 & $\mathrm{P}$ \\
\hline Leaf area $\left(\mathrm{cm}^{2}\right)$ & $26.6 \pm 5.1 \mathrm{ab}$ & $26.3 \pm 4.3 \mathrm{ab}$ & $36.3 \pm 2.3 \mathrm{a}$ & $39.5 \pm 6.3 \mathrm{a}$ & $21.1 \pm 15.0 \mathrm{~b}$ & $0.035^{*}$ \\
Leaf perimeter $(\mathrm{mm})$ & $411.5 \pm 53.8 \mathrm{ab}$ & $413.6 \pm 54.8 \mathrm{ab}$ & $550.3 \pm 32.7 \mathrm{a}$ & $526.2 \pm 60.4 \mathrm{a}$ & $359.3 \pm 21.2 \mathrm{~b}$ & $0.042^{*}$ \\
Leaf length to leaf width ratio & $0.70 \pm 0.012$ & $0.72 \pm 0.029$ & $0.75 \pm 0.032$ & $0.69 \pm 0.030$ & $0.78 \pm 0.030$ & $0.155^{\text {ns }}$ \\
Leaf water content & $0.64 \pm 0.016$ & $0.66 \pm 0.016$ & $0.62 \pm 0.024$ & $0.66 \pm 0.004$ & $0.61 \pm 0.022$ & $0.246^{\text {ns }}$ \\
Specific leaf area $\left(\mathrm{cm}^{2} / \mathrm{g}\right)$ & $205.4 \pm 14.0$ & $220.2 \pm 22.4$ & $197.3 \pm 11.1$ & $202.5 \pm 8.3$ & $188.8 \pm 16.8$ & $0.696^{\text {ns }}$ \\
\hline
\end{tabular}

The data are means $\pm S E(n=5)$. Different letters indicate significant differences $(p \leq 0.05)$ with Duncan multiple range test. Significance level: * $0.01<\mathrm{P} \leq 0.05$; ns $\mathrm{P}>0.05$ 
Table. 3 Leaf physiological traits of A. truncatum seedlings under different nitrogen deposition regimes

\begin{tabular}{|c|c|c|c|c|c|c|}
\hline $\begin{array}{l}\text { Nitrogen load level ( } g \\
\left.\mathrm{~m}^{-2} \mathrm{y}^{-1}\right)\end{array}$ & 0 & 3 & 6 & 10 & 20 & $\mathrm{P}$ \\
\hline $\mathrm{E}\left(\mathrm{mmol} \mathrm{H}_{2} \mathrm{O} \mathrm{m}^{-2} \mathrm{~s}^{-1}\right)$ & $2.42 \pm 0.126 \mathrm{a}$ & $2.44 \pm 0.243 \mathrm{a}$ & $2.65 \pm 0.221 \mathrm{a}$ & $2.22 \pm 0.213 \mathrm{ab}$ & $1.74 \pm 0.0805 \mathrm{~b}$ & $0.030^{*}$ \\
\hline $\mathrm{Gs}\left(\mathrm{mmol} \mathrm{H} \mathrm{O} \mathrm{m}^{-2} \mathrm{~s}^{-1}\right)$ & $181.86 \pm 16.64 \mathrm{ab}$ & $179.55 \pm 12.14 \mathrm{ab}$ & $205.86 \pm 13.89 a$ & $166.32 \pm 9.48 \mathrm{bc}$ & $131.78 \pm 7.38 \mathrm{c}$ & $0.007^{* *}$ \\
\hline $\mathrm{A}\left(\mathrm{umol} \mathrm{CO} \mathrm{CO}^{-2} \mathrm{~s}^{-1}\right)$ & $13.92 \pm 0.57 \mathrm{~b}$ & $14.95 \pm 0.89 \mathrm{ab}$ & $16.56 \pm 0.66 \mathrm{a}$ & $14.79 \pm 0.42 \mathrm{ab}$ & $13.05 \pm 0.60 \mathrm{~b}$ & $0.014^{*}$ \\
\hline $\mathrm{Ci}\left(\mathrm{umol} \mathrm{mol}^{-1}\right)$ & $262.31 \pm 8.60 \mathrm{a}$ & $254.13 \pm 4.66 \mathrm{a}$ & $256.74 \pm 8.34 \mathrm{a}$ & $244.39 \pm 5.05 \mathrm{ab}$ & $229.96 \pm 8.13 b$ & $0.037^{*}$ \\
\hline WUEi $\left(\mathrm{mmol} \mathrm{mol}^{-1}\right)$ & $5.83 \pm 0.46$ & $6.22 \pm 0.25$ & $6.41 \pm 0.49$ & $6.85 \pm 0.56$ & $7.53 \pm 0.40$ & $0.115^{\mathrm{ns}}$ \\
\hline $\mathrm{F}_{\mathrm{v}} / \mathrm{F}_{\mathrm{m}}$ & $0.792 \pm 0.0039 \mathrm{~b}$ & $0.792 \pm 0.0024 \mathrm{~b}$ & $0.800 \pm 0.0049 a b$ & $0.811 \pm 0.0018 \mathrm{a}$ & $0.798 \pm 0.0047 \mathrm{~b}$ & $0.011^{*}$ \\
\hline Yield & $0.31 \pm 0.0076 \mathrm{ab}$ & $0.30 \pm 0.014 \mathrm{~b}$ & $0.35 \pm 0.0073 \mathrm{a}$ & $0.35 \pm 0.015 \mathrm{a}$ & $0.31 \pm 0.020 \mathrm{ab}$ & $0.038^{*}$ \\
\hline Etr & $51.73 \pm 1.28 \mathrm{ab}$ & $50.72 \pm 2.41 \mathrm{~b}$ & $58.86 \pm 1.24 \mathrm{a}$ & $59.20 \pm 2.61 \mathrm{a}$ & $52.07 \pm 3.45 \mathrm{ab}$ & $0.038^{*}$ \\
\hline qP & $0.576 \pm 0.017 b$ & $0.566 \pm 0.015 b$ & $0.693 \pm 0.0089 a$ & $0.661 \pm 0.011 \mathrm{a}$ & $0.565 \pm 0.034 b$ & $0.000^{* *}$ \\
\hline $\mathrm{qN}$ & $0.700 \pm 0.010$ & $0.701 \pm 0.022$ & $0.747 \pm 0.0071$ & $0.734 \pm 0.020$ & $0.693 \pm 0.018$ & $0.114^{\mathrm{ns}}$ \\
\hline chlorophyll a (mg g $\left.{ }^{-1}\right)$ & $1.41 \pm 0.134$ & $1.56 \pm 0.120$ & $1.43 \pm 0.068$ & $1.42 \pm 0.096$ & $1.49 \pm 0.151$ & $0.884^{\mathrm{ns}}$ \\
\hline chlorophyll b ( $\left.\mathrm{mg} \mathrm{g}^{-1}\right)$ & $0.69 \pm 0.070$ & $0.77 \pm 0.059$ & $0.71 \pm 0.034$ & $0.70 \pm 0.047$ & $0.72 \pm 0.078$ & $0.903^{\text {ns }}$ \\
\hline
\end{tabular}

The data are means \pm SE ( $\mathrm{n}=5$ for gas exchange parameters and chlorophyll fluorescence parameters, $\mathrm{n}=6$ for chlorophyll a and chlorophyll b). Different letters indicate significant differences $(\mathrm{p} \leq 0.05)$ with Duncan multiple range test. Significance level: * $0.01<\mathrm{P} \leq 0.05$; ns $\mathrm{P}>0.05$

E, Transpiration rate; Gs, Stomatal conductance; A, Net photosynthetic rate; Ci, Intercellular CO2 concentration; $\mathrm{F}_{v} / \mathrm{F}_{\mathrm{m}}$, maximum PSII quantum yield; Yield, effective quantum yield; Etr, relative photosynthetic electron transport; qN, non-photochemical quenching; qP, photochemical quenching

width ratio, leaf water content and specific leaf area did not display any significant differences.

$\mathrm{A}_{\max }$ (maximal net photosynthetic rate), $\mathrm{I}_{\mathrm{s}}$ (light saturation point), $\mathrm{I}_{c}$ (light compensation point), $\mathrm{Rd}$ (dark respiration rate) and $\mathrm{R}^{2}$ calculated from the light response curve are $13.99 \pm 0.020 \mu \mathrm{mol} \mathrm{CO} \mathrm{m}^{-2} \mathrm{~s}^{-1}$, $1565.74 \pm 74.80 \mu \mathrm{mol} \mathrm{m}^{-2} \mathrm{~s}^{-1}, 13.68 \pm 3.08 \mu \mathrm{mol} \mathrm{m}^{-2}$ $\mathrm{s}^{-1}, 0.86 \pm 0.44 \mu \mathrm{mol} \mathrm{CO} \mathrm{m}^{-2} \mathrm{~s}^{-1}$ and $0.996 \pm 0.0013$ $(n=3)$, respectively. The curve becomes relatively flat when the photosynthetically active radiation reaches approximately $1200 \mu \mathrm{mol} \mathrm{m}^{-2} \mathrm{~s}^{-1}$.

Physiological indexes, including concentrations of chlorophyll, gas exchange parameters, chlorophyll fluorescence parameters, are demonstrated in Table 3. All gas exchange parameters and chlorophyll fluorescence parameters, except non-photochemical quenching and instantaneous water use efficiency, were significantly different among five treatments, displaying similar trend: an increase with the increase in nitrogen supply and a slight decrease when addtion reached $20 \mathrm{~g} \mathrm{~N} \mathrm{~m}^{-2} \mathrm{y}^{-1}$. Non-photochemical quenching initially increased and then decreased in high and extremely high nitrogen load conditions. However, instantaneous water use efficiency increased with the increase of nitrogen addition mount. $\mathrm{F}_{\mathrm{v}} / \mathrm{F}_{\mathrm{m}}$ values fluctuated around 0.8 in five nitrogen addition conditions. Net photosynthetic rate, $\mathrm{F}_{\mathrm{v}} / \mathrm{F}_{\mathrm{m}}$, Yield, Etr and $\mathrm{qP}$ did not exhibit significant differences between control and N4 conditions. None of the chlorophyll content parameters, including chlorophyll a, chlorophyll b, and chlorophyll a to chlorophyll $b$ ratio, were significantly different under various nitrogen addition conditions.

\section{Discussion}

\section{Growth characteristics}

Leaf area and leaf perimeter represent the size of the leaf, which is the main part of a plant to receive the sunlight. Almost all the growth and biomass parameters displayed significant changes; only part of leaf traits showed such changes. The increased growth parameters, total biomass and leaf size in N2 and N3 conditions indicated that the nitrogen supply can stimulate growth of plants to same extent. However, growth parameters, total biomass and leaf size dropped significantly in the N4 condition compared with that of N3. Thus the facilitation effect of nitrogen deposition was limited when nitrogen addition reached $20 \mathrm{~g} \mathrm{~N} \mathrm{~m}^{-2} \mathrm{y}^{-1}$. Therefore, slight nitrogen deposition can promote the growth while facilitating decreases in the case of high nitrogen deposition. This phenomenon was accordant with previous research (Nakaji et al., 2001).

It has been reported that deposition of nitrogen would reduce the root to shoot ratio (Zhao and Liu 2009; Zhou et al. 2011). However, it was not the case in our study where the biomass allocation characteristics did not change significantly among different nitrogen addition regimes, which is agree with a study of aspen clones (Häikiö et al. 2007). We concluded that the biomass allocation pattern was less sensitive than biomass in response to nitrogen supply, and that it will take a longer time for biomass allocation patterns to display the differences.

Specific leaf area has a negative relationship with the leaf thickness; thinner leaves (leaves with larger specific leaf area) require less photosynthetic machinery per unit area (Burns 2004), hence increase 
the photosynthetic capacity. Leaf length to leaf width ratio and leaf water content represents the shape of the leaf and water regime of plant, respectively. $\mathrm{Ni}$ trogen precipitation has a remarkable impact on the size of the leaves but not on shape and physiological properties such as the leaf length to width ratio, leaf water content, and specific leaf area. The indiscriminate leaf water content among various nitrogen precipitation conditions demonstrated that nitrogen addition treatments have no effects on leaf hydrate condition of well-watered seedlings.

Leaf mass per area, the reciprocal of specific leaf area, was not influenced by $\mathrm{N}$ supply. In another study, moderate nitrogen deposition $\left(6 \mathrm{~g} \mathrm{~N} \mathrm{~m}^{-2} \mathrm{y}^{-1}\right)$ resulted in an increased leaf mass per area for Magnolia hypoleuca Siebold et Zucc. and an unchanged leaf mass per area for Quercus mongolica Fischer ex Ledeb. var. crispula (Blume) Ohashi, Carpinus cordata Blume and Prunus ssiori F. Schmidt (Kitaoka et al. 2009). Actually, specific leaf area decreased along the nitrogen load gradient in our study, although the differences were not significant. Specific leaf area is usually positively correlated with light use efficiency (Burns 2004). Furthermore, the potential for higher photosynthetic capacity of the thick leaves may be restricted owing to greater internal shading and diffusion limitations caused by chloroplast stacking in these leaves (Reich et al. 1998). Thus, in the extreme nitrogen deposition situation, where carbon assimilation was the smallest, specific leaf area was the lowest among the five load regimes.

\section{Physiological characteristics}

The chlorophyll content did not increase when nitrogen supply increased, similar to Cryptomeria japonica (Nakaji et al. 2001), but not to other plants (Zhao and Liu 2009; Zhou et al. 2011). The unchanged chlorophyll content may be caused by the assimilation of excess nitrogen by amino acids (Bubier et al. 2011; Rennenberg et al. 2010) and polyamines (Bubier et al. 2011) rather than allocation to chlorophyll. Moreover, excess nitrogen deposition can even lead to a decrease of chlorophyll content (Gaio-Oliveirao et al. 2004). The explanation of the various responses among different species may be that the $\mathrm{N}$-sensitivity of species varied prominently (Nakaji et al. 2001).

$\mathrm{F}_{\mathrm{v}} / \mathrm{F}_{\mathrm{m}}$, Yield, Etr, $\mathrm{qP}$ and $\mathrm{qN}$ reflect the maximal quantum yield of PSII (Boussadia et al. 2008), the practically quantum yield of PSII, the relative quantity of electrons passing through PSII during steadystate photosynthesis (Dai et al. 2009; Tezara et al. 2003), the proportion of PSII reaction centers that are open (Dai et al. 2009; Maxwell and Johnson 2000), and the degree of plants efficiently-dissipated energy trapped at PSII in the form of heat (Wu et al. 2008), respectively. It has been suggested that lower amounts of chlorophyll along with lower content of nitrogen can be the cause of lower basal $\mathrm{F}_{\mathrm{r}} /$ $\mathrm{F}_{\mathrm{m}}$ (Jiménez et al. 2009). However, this was not the case in our study as the chlorophyll content did not show any significant changes (Table 3 ). The value of $\mathrm{F}_{\mathrm{v}} / \mathrm{F}_{\mathrm{m}}$ close to 0.8 , which is considered the reference value for healthy leaves (Björkman and Demmig 1987), revealed that the photosynthetic apparatus of A. truncatum is not destructively destroyed by high nitrogen addition. This may be the intrinsic reason of the reversibility of some effects derived from nitrogen deposition (Clark and Tilman 2008).

The quantum yield of PSII is expected to be lowered when non-photochemical quenching (qN) increases, as $\mathrm{qN}$ is associated with a thermal deactivation of PSII excitation (Boussadia et al. 2008; Weis and Berry 1987). However, our study did not support this expectation, as Yield was comparatively stable under moderate and high nitrogen conditions when $\mathrm{qN}$ increased. This may be due to the increase of qP, since high qP is advantageous for the separation of the electric charge in the reaction center, and is beneficial to electron transport and PSII yield (Dai et al. 2009; Guo et al. 2006). This observation was confirmed by the relatively high Etr of high and moderate nitrogen addition seedlings. Although chlorophyll content did not show any remarkable differences, the photosynthetic efficiency of chloroplast displayed a variation trend, along with the similar variation trend of specific leaf area and biomass.

Net photosynthesis rate increased initially and then decreased in severe nitrogen load condition, revealed that high nitrogen deposition restricted the facilitation effect. This trend is in accordance with Cryptomeria japonica and Pinus densiflora (Nakaji et al. 2001) but contradict with Malcolmia Africana and Bassia hyssopifolia where no decrease of net photosynthesis rate were observed (Zhou et al. 2011). The reductions in stomatal conductance and transpiration rate and increase in water use efficiency caused by high nitrogen load suggest that high nitrogen load induced mild drought stress rather than severe drought stress in which the decreased net photosynthesis rate of seedlings in severe drought condition was mainly due to non-stomatal limitations (Wu et al. 2008). Leaf water content did not change along the decreasing transpiration rate, stomatal conductance and net photosynthesis rate. Therefore, the seedlings under high nitrogen load stress prioritize optimization of water utilization in leaf rather than carbon sequestration, which can be seen as a kind of trade-off. This might be validated by instantaneous water use efficiency (Table 3), which kept increasing with the increasing load amount.

Nitrogen deposition including both ammonium and nitrate could cause a nutrient imbalance and nutrient deficiencies in the plant (Berger and Glatzel 
2001). The activity of Rubisco was closely correlated with certain ratios of nutrients, and nutrient imbalance of $\mathrm{P}$ relative to $\mathrm{N}$ could deplete the protein synthesis and quantity of Rubisco (Nakaji et al. 2001). Therefore the nitrogen to cation imbalance in the leaves may account for the reduction of photosynthesis efficiency in N4 condition compared with the N3 saplings, resulting in the reduction of total biomass as well. Furthermore, even low-level nitrogen deposition would bring negative effects in a long term (Clark and Tilman 2008). Thus, we can infer that the growth of $A$. truncatum in $\mathrm{N} 4$ conditions might be restrained compared with the control seedlings if the amount of nitrogen deposition entered in the next growing season.

Photosynthesis rate, $\mathrm{F}_{v} / \mathrm{F}_{\mathrm{m}}$ and Yield in N4 condition did not display lower values than the control, which indicated that the high nitrogen addition did not play a positive role but also did not restrict the efficiency of photosynthesis. This trend can be the cause of total biomass in $\mathrm{N} 4$ condition, which did not show significant differences between N4 and NO conditions.

\section{Threshold of nitrogen deposition for $A$. truncatum}

Greenhouse pot experiments have been successfully used for investigations of the impact of nitrogen deposition on vegetation (Berger and Glatzel 2001; Flückiger and Braun 1998). Trees can increase productivity in response to nitrogen fertilization by increasing photosynthetic rates, and leaf area (Elvir et al. 2006). In our study, both of these two parameters, i.e. the net photosynthetic rate and leaf area displayed the corresponding trend with that of biomass. Carbon sequestration by vegetation will be raised by nitrogen deposition when nutritional deficiencies occur in soil, and will decrease when nitrogen saturation occurs (Hyvönen et al. 2006). The presented study does not fully support this view of point as the available soil nitrogen content did not reach saturation (Table 1) although biomass and most growth parameters decreased in N5 condition. Whether nutrient deficiencies occur in the field will depend on both the chemical form of $\mathrm{N}$ inputs and the supply of a given nutrient from the soil and the atmosphere (Wilson and Skeffington 1994).

Based on our observations, we conclude that there is a critical amount of nitrogen deposition for A. truncatum in its environment, leading to a threshold of nutrient imbalance that is harmful to plant growth. However, the significance of nitrogen load effects on some indicators may change with time (Häikiö et al. 2007; Magill et al. 2000; Yamaguchi et al. 2012); in fact, the critical load decreased with longer deposi- tion (Fenn et al. 2008). The reason in all probability is that the nitrogen content in the soil and atmospheric precipitation together determine the nitrogen condition of plants and the nitrogen can be accumulated in the pedosphere (Phoenix et al. 2012). Besides, the buffer capacity of soil can greatly affect the critical load (Bobbink et al. 2003) and more complex and interconnected processes in the forests results in a higher critical load than ecosystem partly due to the large nitrogen storage pool of forest ecosystems entitling a greater buffer capacity to nitrogen load (Pardo et al. 2011). Furthermore, nitrogen acquisition of trees from the soil depends on both developmental factors and external factors (Rennenberg et al. 2010) and even low nitrogen load may induce effects in a long time scale though accumulating (Phoenix et al. 2012). Thus, the traditional concept of critical load should be revised and be defined with a time criterion. In our research, the critical load for suppressing the facilitation is approximately $10 \mathrm{~g} \mathrm{~N} \mathrm{~m}^{-2} \mathrm{y}^{-1}$ for A. truncatum in this area of East Asia for the growing season of 2011.

In most northern temperate and boreal forests, biomass production is chronically restricted by lack of N (Dentener et al. 2006; Vitousek and Howarth 1991). In the year 2030, the ambient amount of nitrogen deposition in East Asia, Europe and northern America, will range approximately from 2 to $5 \mathrm{~g} \mathrm{~N}$ $\mathrm{m}^{-2} \mathrm{y}^{-1}$, with a maximum deposition greater than $5 \mathrm{~g} \mathrm{~N} \mathrm{~m}^{-2} \mathrm{y}^{-1}$ (by both current emissions legislation scenario and the SRES A2 emissions scenario) (Dentener et al. 2006; Reay et al. 2008). Thus, assuming the average nitrogen supply in the soil of Europe and Northern America are no more than that of East Asia and the soil conditions are similar, A. truncatum in its distribution area will probably get benefits from the deposition, at least for a short term.

As the responses to nitrogen deposition of species (Nakaji et al. 2001; Yamaguchi et al. 2012) or clones of the same species (Häikiö et al. 2007) varied prominently, and the degree of facilitation or suppression of nitrogen deposition differs among species (Pardo et al. 2011; Thomas et al. 2010) as did the regional heterogeneity of nitrogen load, it is likely that the composition of community vegetation is undergoing changes, possibly to more nitrophilic species (Pardo et al. 2011) in some places in the world, specially the regions with high nitrogen deposition.

Extreme high nitrogen deposition can impose restrictions on the growth of $A$. truncatum, in both morphological and physiological characteristics, compared with low and moderate nitrogen deposition. This restriction did not devastate the photosynthetic apparatus during one growing season. Long-term research is needed to confirm if the shoot to root ratio would change and element concentration of leaves should be measured to test our hypothesis. Further 
measurements of adult trees should be applied to confirm our conclusion.

\section{Acknowledgments}

We express our deep gratitude to Chong Fang, Ning Du, Wenjuan Ding, Huan He, Xiangfeng Tan, Zewen Liu for their help during the experiments, to a professional editing company "Edanz Group" for language editing. The research was supported by National Science Foundation of China (No. 31270374) and Independent Innovation Project of Shandong University (No. 2011DX008).

\section{References}

Aber J.D., Goodale C.L., Ollinger S.V., Smith M.-L., Magill A.H., Martin M.-E., Hallett R.A., Stoddard J.L. 2003. Is nitrogen deposition altering the nitrogen status of northeastern forests? Bioscience 53: 375-389. http://dx.doi.org/10.1641/0006-35 68(2003)053[0375:INDATN]2.0.CO;2

Berger T.W., Glatzel G. 2001. Response of Quercus petraea seedlings to nitrogen fertilization. Forest Ecology and Management 149: 1-14. http://dx. doi.org/10.1016/S0378-1127(00)00541-7

Björkman O., Demmig B. 1987. Photon yield of $\mathrm{O}_{2}$ evolution and chlorophyll fluorescence characteristics and $77 \mathrm{~K}$ among vascular plants of diverse origin. Planta 170: 489-504. http://dx.doi. org/10.1007/BF00402983

Bobbink R., Ashmore M., Braun S., Flückiger W., Wyngaert I.J.J.V.D. 2003 Empirical nitrogen critical loads for natural and semi-natural ecosystems: 2002 update. Environmental Documentation No. 164, Swiss Agency for the Environment, Forest and Landscape (SAFEL), Bern, Switzerland.

Boussadia O., Mariem F.B., Mechri B., Boussetta W., Braham M., Hadj S.B.E. 2008. Response to drought of two olive tree cultivars (cv Koroneki and Meski). Scientia Horticulturae 116: 388-393. http://dx.doi.org/10.1016/j.scienta.2008.02.016

Bubier J.L., Smith R., Juutinen S., Moore T.R., Minocha R., Long S., Minocha S. 2011. Effects of nutrient addition on leaf chemistry, morphology, and photosynthetic capacity of three bog shrubs. Oecologia 167: 355-368. http://dx.doi.org/10.1007/ s00442-011-1998-9

Burns K.C. 2004. Patterns in specific leaf area and the structure of a temperate heath community. Diversity and Distributions 10: 105-112. http://dx.doi. org/10.1111/j.1366-9516.2004.00058.x

Clark C.M., Tilman D. 2008. Loss of plant species after chronic low-level nitrogen deposition to prairie grasslands. Nature 451: 712-715. http:// dx.doi.org/10.1038/nature06503
Dai Y., Shen Z., Liu Y., Wang L., Hannaway D., Lu H. 2009. Effects of shade treatments on the photosynthetic capacity, chlorophyll fluorescence, and chlorophyll content of Tetrastigma hemsleyanum Diels et Gilg. Environmental and Experimental Botany 65: 177-182. http://dx.doi.org/10.1016/j. envexpbot.2008.12.008

Dentener F., Drevet J., Lamarque J.F., Bey I., Eickhout B., Fiore A.M., Hauglustaine D., Horowitz L.W., Krol M., Kulshrestha U.C., Lawrence M., Galy-Lacaux C., Rast S., Shindell D., Stevenson D., Noije T., Atherton C., Bell N., Bergman D., Butler T., Cofala J., Collins B., Doherty R., Ellingsen K., Galloway J., Gauss M., Montanaro V., Müller J.F., Pitari G., Rodriguez J., Sanderson M., Solmon F., Strahan S., Schultz M., Sudo K., Szopa S., Wild O. 2006. Nitrogen and sulfur deposition on regional and global scales : A multimodel evaluation. Global Biogeochemical Cycles 20: 1-21. http:// dx.doi.org/10.1029/2005GB002672

Elvir J.A., Wiersma G.B., Day M.E., Greenwood M.S., Fernandez I.J. 2006. Effects of enhanced nitrogen deposition on foliar chemistry and physiological processes of forest trees at the Bear Brook Watershed in Maine. Forest Ecology and Management 221: 207-214. http://dx.doi.org/10.1016/j.foreco.2005.09.022

Fenn M.E., Jovan S., Yuan F., Geiser L., Meixner T., Gimeno B.S. 2008. Empirical and simulated critical loads for nitrogen deposition in California mixed conifer forests. Environmental Pollution 155: 492-511. http://dx.doi.org/10.1016/j.envpol.2008.03.019

Flückiger W., Braun S. 1998. Nitrogen deposition in Swiss forests and its possible relevance for leaf nutrient status, parasite attacks and soil acidification. Environmental Pollution 102: 69-76. http:// dx.doi.org/10.1016/S0269-7491(98)80017-1

Häikiö E., Freiwald V., Silfver T., Beuker E., Holopainen T., Oksanen E. 2007. Impacts of elevated ozone and nitrogen on growth and photosynthesis of European aspen ( Populus tremula) and hybrid aspen $(P$. tremula $\times$ Populus tremuloides $)$ clones. Canadian Journal of Forest Research 37: 2326-2336. http://dx.doi.org/10.1139/X07-084

Gaio-Oliveira G., Dahlman L., Palmqvist K., Máguas C. 2004. Ammonium uptake in the nitrophytic lichen Xanthoria parietina and its effects on vitality and balance between symbionts. Lichenologist 36: 75-86. http://dx.doi.org/10.1017/ S0024282904014124

Galloway J.N., Dentener F.J., Capone D.G., Boyer E.W., Howarth R.W., Seitzinger S.P., Asner G.P., Cleveland C.C., Green P.A., Holland E.A., Karl D.M., Michaels A.F., Porter J.H., Townsend A.R., Vöosmarty C.J. 2004. Nitrogen cycles: past, pres- 
ent, and future. Biogeochemistry 70: 153-226. http://dx.doi.org/10.1007/s10533-004-0370-0

Genty B., Briantais J.M., Baker N.R. 1989. The relationship between the quantum yield of photosynthetic electron transport and quenching of chlorophyll fluorescence. Biochimica et Biophysica Acta 990: 87-92. http://dx.doi.org/10.1016/ S0304-4165(89) 80016-9

Guo H.X., Liu W.Q., Shi Y.C. 2006. Effects of different nitrogen forms on photosynthetic rate and the chlorophyll fluorescence induction kinetics of flue-cured tobacco. Photosynthetica 44: 140-142. http://dx.doi.org/10.1007/s11099-005-0170-3

Hyvönen R., Agren G.I., Linder S., Persson T., Cotrufo M.F., Ekblad A., Freeman M., Grelle A., Janssens I.A., Jarvis P.G., Kellomäki S., Lindroth A., Loustau D., Lundmark T., Norby R.J., Oren R., Pilegaard K., Ryan M.G., Sigurdsson B.D., Strömgren M., Oijen M., Wallin G. 2006. The likely impact of elevated $\left[\mathrm{CO}_{2}\right]$, nitrogen deposition , increased temperature and management on carbon sequestration in temperate and boreal forest ecosystems : a literature review. New Phytologist 173: 463-480. http://dx.doi.org/10.1111/j.14698137.2007.01967.x

Jiménez M.D., Pardos M., Puértolas J., Kleczkowski L.A., Parados J.A. 2009. Deep shade alters the acclimation response to moderate water stress in Quercus suber L. Forestry 82: 285-298. http://dx. doi.org/10.1093/forestry/cpp008

Kitaoka S., Watanabe Y., Koike T. 2009. The effects of cleared larch canopy and nitrogen supply on gas exchange and leaf traits in deciduous broad-leaved tree seedlings. Tree Physiology 29: 1503-1511. http://dx.doi.org/10.1093/treephys/tpp080

Lichtenthaler H.K., Wellburn A.R. 1983. Determinations of total carotenoids and chlorophylls $\mathrm{a}$ and $\mathrm{b}$ of leaf extracts in different solvents. Biochemical Society Transactions 11: 591-592.

Ma X., Wu L., Ito Y., Tian W. 2005. Application of preparative high-speed counter-current chromatography for separation of methyl gallate from Acer truncatum Bunge. Journal of Chromatography A 1076: 212-215. http://dx.doi.org/10.1016/j. chroma.2005.04.077

Magill A.H., Aber J.D., Berntson G.M., McDowell W.H., Nadelhoffer K.J., Melillo J.M., Steudler P. 2000. Long-term nitrogen additions and nitrogen saturation in two temperate forests. Ecosystems 3: 238-253. http://dx.doi.org/10.1007/ s100210000023

Maxwell K., Johnson G.N. 2000. Chlorophyll fluorescence - a practical guide. Journal of Experimental Botany 51: 659-668. http://dx.doi.org/10.1093/ jexbot/51.345.659

Nakaji T., Fukami M., Dokiya Y., Izuta T. 2001. Effects of high nitrogen load on growth , photosyn- thesis and nutrient status of Cryptomeria japonica and Pinus densiflora seedlings. Trees 15: 453-461.

Nijs I., Ferris R.. Blum H., Hendrey G., Impens I. 1997. Stomatal regulation in a changing climate: a field study using free air temperature increase (FATI) and free air CO2 enrichment (FACE). Plant, Cell and Environment 20: 1041-1050. http://dx.doi. org/10.1111/j.1365-3040.1997.tb00680.x

Nilsson I., Grennfelt P. 1988. Critical Loads for Sulfur and Nitrogen. Report from a Workshop Held at Stokhoster, Sweden, March 19-24, 1988. Miljo Rapport. Nordic Council of Ministers, Copenhagen, Denmark, p. 15.

Pardo L.H., Fenn M.E., Goodale C.L., Geiser L.H., Driscoll C.T., Allen E.B., Baron J.S., Bobbink R., Bowman W.D., Clark C.M., Emmett B., Gilliam, F.S., Greaver T.L., Hall S.J., Lilleskov E.A., Liu L., Lynch J.A., Nadelhoffer K.J., Perakis S.S., Robin-Abbott M.J., Stoddard J.L., Weathers K.C., Dennis R.L. 2011. Effects of nitrogen deposition and empirical nitrogen critical loads for ecoregions of the United States. Ecological Applications 21: 3049-3082. http://dx.doi.org/10.1890/102341.1

Phoenix G.K., Emmett B.A., Britton A.J., Caporn S.J.M., Dise N.B., Helliwell R., Jones L., Leake J.R., Leith I.D., Sheppard L.J, Sowerby A., Pilkington M.G., Rowe E.C., Ashmore M.R., Power S.A. 2012. Impacts of atmospheric nitrogen deposition: responses of multiple plant and soil parameters across contrasting ecosystems in long-term field experiments. Global Change Biology 18: 1197-1215. http://dx.doi.org/10.1111/j.13652486.2011.02590.x

Porter E., Blett T., Potter D.U., Huber C. 2005. Protecting resources on federal lands: implications of critical loads for atmospheric deposition of nitrogen and sulfur. BioScience 55: 603-612. http:// dx.doi.org/10.1641/0006-3568(2005)055[0603:PROFLI]2.0.CO;2

Reay D.S., Dentener F., Smith P., Grace J., Feely R.A. 2008. Global nitrogen deposition and carbon sinks. Nature Geoscience 1: 430-437. http://dx. doi.org/10.1038/ngeo230

Reich R., Ellsworth D.S., Walters M.B. 1998. Leaf structure (specific leaf area) modulates photosynthesis-nitrogen relations: evidence from within and across species and functional groups. Functional Ecology 12: 948-958. http://dx.doi. org/10.1046/j.1365-2435.1998.00274.x

Rennenberg H., Wildhagen H., Ehlting B. 2010. Nitrogen nutrition of poplar trees. Plant Biology 12: 275-291. http://dx.doi.org/10.1111/j.14388677.2009.00309.x

Schreiber U., Schliwa U., Bilger W. 1986. Continuous recording of photochemical and non-photochemical chlorophyll fluorescence with a new 
type of modulation fluorometer. Photosynthesis Research 10: 51-62. http://dx.doi.org/10.1007/ BF00024185

Tezara W., Martinez D., Rengifo E., Herrera A. 2003. Photosynthetic responses of the tropical spiny shrub Lycium nodosum (Solanaceae) to drought, soil salinity and saline spray. Annals of Botany 92: 757-765. http://dx.doi.org/10.1093/aob/ $\operatorname{mcg} 199$

Thomas R.Q., Canham C.D., Weathers K.C., Goodale C.L. 2010. Increased tree carbon storage in response to nitrogen deposition in the US. Nature Geoscience 3: 13-17. http://dx.doi.org/10.1038/ ngeo721

Vitousek P.M., Howarth R.W. 1991. Nitrogen limitation on land and in the sea: how can it occur? Biogeochemistry 13: 87-115. http://dx.doi. org/10.1007/BF00002772

Weis E., Berry J.A. 1987. Quantum efficiency of photosystem II in relation to energy-dependent quenching of chlorophyll fluorescence. Biochimica et Biophysica Acta 894: 198-208. http://dx. doi.org/10.1016/0005-2728(87)90190-3

White J., More D. 2003. Cassell's trees of Britain and Northern Europe.

Wilson E.J., Skeffington R.A. 1994. The effects of excess nitrogen deposition on young Norway spruce trees. Part II The vegetation. Environmental Pollution 86: 153-160. http://dx.doi. org/10.1016/0269-7491(94)90186-4

Wu F.Z., Bao W.K., Li F.L., Wu N. 2008. Effects of water stress and nitrogen supply on leaf gas ex- change and fluorescence parameters of Sophora davidii seedlings. Photosynthetica 46: 40-48. http:// dx.doi.org/10.1007/s11099-008-0008-x

Yamaguchi M., Watanabe M., Tabe C., Naba J., Matsumura H., Kohno Y., Izuta, T. 2012. Effects of sulfur dioxide on growth and net photosynthesis of six Japanese forest tree species grown under different nitrogen loads. Trees 26: 1859-1874. http://dx.doi.org/10.1007/s00468-012-0755-y

Ye Z.-P. 2007. A new model for relationship between irradiance and the rate of photosynthesis in Oryza sativa. Photosynthetica 45: 637-640. http://dx. doi.org/10.1007/s11099-007-0110-5

Zhang X.-Q., Liu J., Welham C.C.V.J., Liu C.-C., Li D.-N., Chen L., Wang R-Q. 2006. The effects of clonal integration on morphological plasticity and placement of daughter ramets in black locust (Robinia pseudoacacia). Flora 201: 547-554. http:// dx.doi.org/10.1016/j.flora.2005.12.002

Zhao C., Liu Q. 2009. Growth and photosynthetic responses of two coniferous species to experimental warming and nitrogen fertilization. Canadian Journal of Forest Research 39: 1-11. http:// dx.doi.org/10.1139/X08-152

Zhou X., Zhang Y., Ji X., Downin, A., Serpe M. 2011. Combined effects of nitrogen deposition and water stress on growth and physiological responses of two annual desert plants in northwestern China. Environmental and Experimental Botany 74: 1-8. http://dx.doi.org/10.1016/j.envexpbot.2010.12.005 